\title{
Sleep coaching: non-pharmacological treatment of non- restorative sleep in Austrian railway shift workers
} \author{
Gerhard Klösch ${ }^{1,2}$ \\ ${ }^{1}$ Institute for Consciousness and Dream Research, Vienna, Austria \\ ${ }^{2}$ Department of Neurology, Medical University of Vienna, Austria \\ ${ }^{3}$ Medical University, Vienna, Austria
}

Brigitte Holzinger ${ }^{1,3}$, Lucille Mayer ${ }^{1}$, Katharina Levec ${ }^{1}$, Melissa-Marie Munzinger ${ }^{1}$, and

[Received in December 2018; Similarity Check in December 2018; Accepted in August 2019]

\begin{abstract}
Sleep coaching by Holzinger \& Klösch ${ }^{\mathrm{TM}}$ is a new, Gestalt therapy-based holistic approach to non-pharmacological treatment of non-restorative sleep. It includes psychotherapeutic aspects which enable participants to improve their sleep quality by developing their own coping strategies as a daily routine. Dream work and relaxation techniques are also part of the programme. The aim of this study was to measure the effectiveness of a two-day sleep coaching seminar on sleep quality, daytime sleepiness, and work and life quality in shift workers employed in an Austrian railway company (Österreichische Bundesbahnen, ÖBB). Thirty shift workers (28 male; mean age $=24 \pm 45.90$, age range $24-56$ years) answered the same survey before and six months after the seminar (baseline and follow-up) containing items of the Pittsburgh Sleep Quality Index (PSQI) and the Epworth Sleepiness Scale (ESS), their chronotype, personality factors, and burnout risk factors. The baseline findings in this group were compared with those of non-completers (who did not take the follow-up survey) $(\mathrm{N}=154)$ to see if the two groups differed significantly enough to create a bias among completers (who took the follow-up survey as well). Groups differed significantly in burnout levels as well as sleep duration, but not in the distribution of critical PSQI and ESS values. The two-day sleep coaching seminar resulted in a significant improvement in total PSQI score and subjective sleep quality and in a significant reduction in diurnal fatigue, sleep latency, and daytime sleepiness. Nevertheless, more research with a larger sample and a longitudinal design is needed to establish the long-term effects of sleep coaching.
\end{abstract}

KEY WORDS: daytime sleepiness; sleep coaching by Holzinger \& Klösch ${ }^{\mathrm{TM}}$; sleep disorders; sleep quality

Currently $19.6 \%$ of Austria's total working population work in shifts, $(20.4 \%$ of men and $18.8 \%$ of women) (1).

Working in (changing) shifts affects several aspects of life and is associated with sleep disorder. Core symptoms are insomnia, excessive daytime sleepiness, loss of normal sleep-wake patterns, reduced alertness, and increased irritability, which, in turn, interfere with the ability to engage in social activities. The estimated prevalence of health problems associated directly with shift work is between $2 \%$ and $5 \%$ in the general population (2). The prevalence of shift work sleep disorder is approximately $10 \%$ in the night and rotating shift work population (3).

Several studies have described the negative effects of shift work on physical health and sleep. These include higher rates of gastrointestinal and cardiovascular diseases among shift workers, especially after 15 to 20 years on the job (4). Moreover, there are clear indicators that long lasting shift work is associated with a higher risk of certain types of cancer (5). Shift workers also have a higher body mass index, which points toward metabolic diseases and diabetes

Corresponding author: Brigitte Holzinger, $\mathrm{PhD}$, Institute for Consciousness and Dream Research, Canongasse 13/1A-1180 Vienna

E-mail: office@traum.ac.at; office@schlafcoaching.org
$(4,6,7)$. Working in shifts is also associated with a higher risk of myocardial infarction, coronary events and ischaemic stroke (8).

As for the psychological effects, the relationship between shift work and burnout is still unclear. One study (9) reported an association between persistent non-standard work schedules and increased emotional exhaustion, stress, and burnout in Canadian workers, and another (10) between longer shift duration and higher burnout risk among nurses.

Workers switching from standard day hours to shift work had a $73 \%$ higher risk of difficulty falling asleep and maintaining sleep and higher probability of these difficulties being reduced after ceasing working in shifts. Some complaints like repeated awakenings, however, may remain even when the workers switch back to standard day hours.

Shift work is also significantly associated with excessive daytime sleepiness and falling asleep at work (11).

Non-restorative sleep is one of the main reasons for impaired social interactions and family life (12).

Irregular work and sleep patterns disrupt and desynchronise biological rhythms and lead to reduced cognitive performance and an increased risk of accidents (13). 
Studies that have investigated the relationship between shift work and chronotypes suggest that evening chronotypes have less regular sleeping habits with shorter bedtimes during the week and longer bedtime over weekend (14). This effect (also known as social jetlag) seems to be more pronounced in morning chronotypes working nights as well as evening chronotypes working early mornings (15). Klösch et al. (16), in turn, reported that evening chronotypes working in shifts had significantly lower subjective sleep quality and longer sleep latencies than morning chronotypes working in shifts.

There are several approaches and teaching tools to help shift workers minimise the adverse effects of working at night or on irregular schedules. For example, Circadian Technologies, Inc. created an on-the-job training programme, conducted by an expert who informs the workers about health issues caused by shift work and about prevention and coping strategies for fatigue and decreased alertness. The training also teaches how to cancel out adverse effects on one's social life. Kerin and Aguirre (17) found that workers who completed the training slept longer, improved their time management skills for work and family, were more emotionally balanced, and reported better overall health. As a consequence of the training, workers also made changes to their sleeping environment to further improve sleep quality and incorporated healthy eating habits in their lifestyle.

However, a more therapy-oriented approach may be necessary to address specific sleep complaints as the main adverse effects of shift work. Historically, this was done with pharmacotherapy (18) but has gradually given way to behavioural sleep medicine, which is based on behaviourism and cognitive psychology and has been successful in treating sleep disorders $(19,20)$. Cognitive behavioural therapy for insomnia (CBT-I) uses various techniques such as sleep hygiene, sleep restriction, stimulus control therapy and relaxation $(19,21)$. The cognitive therapy component is about offering education about sleep to subsequently target dysfunctional beliefs and minimise worries. Sleep hygiene includes a number of practices to promote good sleep quality, such as avoiding stimulants like caffeine and nicotine close to bed time, exercising, and limiting daytime naps. Sleep restriction is another powerful tool to increase sleep pressure by reducing the amount of time spent in bed to more closely match the amount of time spent sleeping. It reduces the sleep onset latency and wake periods at night (22). Stimulus control therapy increases patient's awareness of "going to bed" rituals and advises against bed use for activities other than sleeping (e.g. watching TV). Relaxation therapy such as hypnosis (23), self-hypnosis, autogenous training, and progressive muscle relaxation or biofeedback are also effective in reducing sleep onset latencies and improving sleep quality $(24,25)$. An approach combining these techniques is more effective than simply applying sleep hygiene or cognitive behaviour alone $(26,27)$. Röttger et al. (28) reported that a bundle of interventions called "sleep coaching", which included sleep hygiene and various cognitive behavioural approaches, successfully enhanced the sleep quality and reduced sleep latency of people working at the German Armed Forces.

\section{Sleep coaching by Holzinger \& Klösch}

By combining several approved non-pharmacological techniques into a holistic therapy to resolve sleep complaints, Holzinger and Klösch (29) created an alternative concept of "sleep coaching" (SC) based on the concept of Gestalt therapy. Gestalt therapy addresses biased perceptions and reveals suppressed emotions related to sleep by means of role-playing games, feedback, and sharing. Furthermore, it can detect the source behind "sleep problems" by focusing on the "Gestalt" of the presented "problem", which is also framed by maladaptive daytime behaviours. Gestalt therapy belongs to depth psychology and is also referred to as "therapy of emotions" (30). Holzinger et al. (31) showed that in a Gestalt therapy setting, combined with lucid dreaming techniques, patients suffering from nightmares learned not only to control their dreams but also became aware of the problems behind those nightmares and were able to resolve them. This approach also had positive effects on sleep complaints and daytime functioning.

Sleep coaching includes the above mentioned techniques of CBT-I as well as sleep education and chronotherapy, which have been successful in correcting maladaptive sleep behaviour. Self-hypnosis and various kinds of relaxation techniques as well as autogenic training and meditation, which are also part of "sleep coaching" (20-25).

One essential part of this new approach is dream work, which not only provides coping strategies for nightmares but also enhances the beneficial effects of lucid dreaming and working through dreams as an essential part of the sleep process (31). At the Institute for Consciousness and Dream Research (ICDR) this new holistic approach is taught at seminars and courses offered to private companies and patient groups. Sleep coaching is also a postgraduate training course at the Medical University of Vienna.

\section{Aim of the study}

The aim of this study was to evaluate the effectiveness of a two-day seminar for shift workers of Austria's biggest railway company Österreichische Bundesbahnen (ÖBB) based on the subjective ratings of volunteers who completed a comprehensive questionnaire on sleep quality and sleepiness before (baseline) and after the intervention (follow-up).

\section{PARTICIPANTS AND METHODS}

\section{Participants}

This interventional prospective study included 30 shift workers (of whom 28 men; mean age $=24 \pm 45.90$, age range 
24-56 years) of various occupations, who had worked in shifts continuously for $300 \pm 126.54$ months in average.

\section{Methods}

In a self-rated questionnaire consisting of 40 items, participants were first asked to fill in demographic information. They were then asked about their shift schedules and if their working schedule affected them physically, psychologically, socially, or mentally. More than one answer was possible.

The participants then chose their chronotype from three categories: "morning", "evening", or "in between". They also evaluated their perfectionism and burnout by answering two questions about perfectionism ("Do others think you are a perfectionist?", "Do you think you are a perfectionist?") and two questions about burnout ("Do you often feel lack of energy?" and "Do you sometimes feel confused, as if not quite yourself?"). In addition, the participants were asked if they suffered from sleep problems and if these problems affected their quality of life. Responses to these six items ranged on a 4-point-scale from "not at all true" (0 points), "partly true" (1 point) to "mostly true" ( 2 points) and "completely true" (3 points). An average score was then calculated for the categories burnout and perfectionism.

All participants were asked to complete the Pittsburgh Sleep Quality Index (PSQI, validated German version) (32, 33), an established measurement for sleep quality. Based on seven components, namely subjective sleep quality, sleep latency, sleep duration, habitual sleep efficiency, sleep disturbances, use of sleeping medication, and daytime dysfunction, a total score between 0 and 21 was calculated, where 21 indicated the poorest sleep quality and 0 no sleep problems at all. The threshold for poor sleep quality was the total score above 5 (33).

The Epworth Sleepiness Scale (ESS, German version) was included to measure daytime sleepiness. Its reported reliability is alpha $=0.82$ (34). Participants rated the likelihood to doze off or fall asleep in eight everyday situations (e.g. watching TV) on a scale from 0 ("would never doze off") to 3 ("high chance to doze off") to obtain a total score between 0 and 24 (where 24 indicated the highest diurnal fatigue). The threshold for increased diurnal fatigue was the total score of $>10$ (35).

\section{Chronotypes}

The shift workers in our study were categorised in three chronotype groups: morning-type, evening-type, and indifferent, the last corresponding to the choice of "in between" in self-evaluation. Morning chronotypes prefer early sleeping and awakening times, whereas evening chronotypes prefer late sleeping and awakening. According to recent studies, most people describe themselves as indifferent chronotypes, whereas about $25 \%$ rate themselves as evening or morning types $(14,15,36)$.

\section{Questionnaire administration}

The questionnaire was available online to all workers at ÖBB who volunteered to participate 14 days ahead of the SC seminar to obtain baseline information. They were informed of the objectives and methods used in the survey and of the confidentiality of participant information and had to give informed consent before starting the online survey (www.sleepcoaching.org). All responses were analysed and condensed into a report distributed to the participants during SC seminars. Six months after the seminars, the participants were invited to fill in the questionnaire again for follow-up.

In total, 184 ÖBB shift workers who took the sleep coaching seminar completed the baseline survey between 24 September 2015 and 4 June 2017. Of them 30 also completed the follow-up survey. Non-shift workers who took part in the programme were not included in this study, because the intervention is specifically designed for sleep problems due to shift work.

\section{Statistical analysis}

To see if shift workers who filled in the questionnaire before and after the seminar $(\mathrm{N}=30)$ differed from those only responding before $(\mathrm{N}=154)$, we compared the baseline findings of the two groups. Total scores in sleep quality (PSQI) and daytime sleepiness (ESS) were compared to see how many participants exceeded pre-defined threshold scores. Chi-square tests were performed to see if distributions of the threshold scores in PSQI and ESS differed significantly between the two groups.

Statistical analysis included the results of the 30 respondents who completed both the questionnaire both at baseline and follow-up to see if the SC seminar helped them improve their sleep behaviour. For significant results, effect sizes were calculated using the Cohen's d formula $d=t_{c}[2(1-r) / n]^{1 / 2}(37)$. The results were presented as means with standard deviations.

For statistical analysis the threshold for the rejection of the null hypothesis was set to 0.05 . All statistical analyses were performed using the IBM SPSS Statistics for Windows, version 24.0. (Armonk, NY, USA).

\section{RESULTS}

\section{Baseline comparisons between groups}

To see if shift workers who completed the questionnaire before and after the seminar (completers, $\mathrm{N}=30$ ) differed from those only responding before (non-completers, $\mathrm{N}=154$ ), we compared the baseline findings of the two groups. Completers (of whom 28 men; mean age $=24 \pm 45.90$, age range $24-56$ years) had worked in shifts continuously for $300 \pm 126.54$ months in average. Non-completers (of whom 137 men; mean age $=45.90$, age range 22-58) had worked in shifts for $267 \pm 133.29$ months in average. Means and standard deviations are listed in Table 1, and one-way 
ANOVA was used to see if the results of the two groups differed significantly. F-tests were done to check for homogeneity of variance. Significant differences were found for burnout $[F(1,182)=5.13, \mathrm{p}<0.025]$. ANOVA could not be calculated for sleep duration and chronotype, because of great variances in distribution. For those variables, instead, we used Welch's $t$-test, and a significant difference was found for sleep duration $[F(1,182)=20.91, \mathrm{p}<0.001]$.

Chi-square test was used to check difference in the distribution of categorical variables. No difference was found in regard to the distribution of PSQI threshold score indicating poor sleep quality $(>5)\left(\chi^{2}=0.203, \mathrm{df}=1, \mathrm{p}=0.653\right)$ or sleep disorder requiring clinical intervention $(>10)$ $\left(\chi^{2}=0.039, \mathrm{df}=1, \mathrm{p}=0.843\right)$. The two groups also did not differ significantly in the number of participants scoring $>10$ in $\operatorname{ESS}\left(\chi^{2}=0.312, \mathrm{df}=1, \mathrm{p}=0.577\right)$, implying no difference in the severity of sleep problems (Table 2 ).

Having therefore reasonably excluded bias, we proceeded with the analysis of sleep coaching effects in the completer group.

\section{Baseline and follow-up}

Regarding chronotypes, 3 of the 30 respondents (10\%) declared themselves morning, 14 (46\%) evening, and 12 (40\%) neither evening nor morning types, whereas one participant did not answer.

Perfectionism scores did not differ significantly between the baseline and follow-up questionnaires $[\mathrm{t}(29)=1.35$, $\mathrm{p}=0.187]$. Table 3 shows significant improvement in total PSQI score and subjective sleep quality and a significant drop in diurnal fatigue, sleep latency, and daytime sleepiness six months after the seminar. A medium treatment effect was found for all these variables. Life quality improved significantly with a small effect size. No improvement was observed for the PSQI variable sleep duration and burnout. The remaining variables - sleep disorders, consumption of soporifics, sleep efficiency and sleep issues - showed some non-significant improvement.

Although some improvement was observed, the threshold $(>5)$ indicating poor sleep quality was still exceeded by the group in the follow-up.

BMI did not rise significantly $[\mathrm{t}(28)=0.65, \mathrm{p}=0.521]$ six months after the seminar $(28.39 \pm 4.70$ vs $28.22 \pm 4.23)$.

Figure 1 compares participant complaints due to shift work before and after the SC seminar. While complaints of physical nature and those related to social life diminished, psychological and mental complaints increased (Figure 2).

\section{DISCUSSION AND CONCLUSION}

The SC seminar showed a significant improvement in the total PSQI score, subjective sleep quality, life quality, diurnal fatigue, sleep latency, and daytime sleepiness (ESS), but did not affect sleep duration and burnout risk. It also showed a slight but statistically not significant improvement in sleep disorders, sleep efficiency, and sleep issues.

Table 1 Comparison of PSQI, ESS, burnout, sleep issues, life quality, and impact on life at baseline between participants who completed (completers) the follow-up questionnaire and those who did not (non-completers)

\begin{tabular}{lcc}
\hline & $\begin{array}{c}\text { Completers } \\
\mathbf{N}=\mathbf{3 0} \\
\text { mean } \pm \text { SD }\end{array}$ & $\begin{array}{c}\text { Non-completers } \\
\mathbf{N}=\mathbf{1 5 4}\end{array}$ \\
\cline { 2 - 3 } PSQI & & \\
\hline Total score & $7.07 \pm 2.79$ \\
\hline Subjective sleep quality & $1.43 \pm 0.50$ & $7.69 \pm 3.29$ \\
\hline Sleep disorders & $1.23 \pm 0.43$ & $1.44 \pm 0.65$ \\
\hline Consumption of soporifics & $0.17 \pm 0.65$ & $1.24 \pm 0.50$ \\
\hline Diurnal fatigue & $1.30 \pm 0.70$ & $0.14 \pm 0.55$ \\
\hline Sleep duration & $0.47 \pm 0.73$ & $1.36 \pm 0.75$ \\
\hline Sleep latency & $1.67 \pm 0.96$ & $1.15 \pm 1.03^{* *}$ \\
\hline Sleep efficiency & $0.83 \pm 1.09$ & $1.52 \pm 0.92$ \\
\hline ESS & & $0.84 \pm 1.05$ \\
\hline Daytime sleepiness & $8.73 \pm 3.75$ & $8.43 \pm 4.40$ \\
\hline Additional variables & & $1.54 \pm 0.96$ \\
\hline Perfectionism & $1.75 \pm 0.73$ & $1.34 \pm 0.69 *$ \\
\hline Burnout & $1.03 \pm 0.60$ & $1.85 \pm 0.90$ \\
\hline Subjective sleep issues & $1.90 \pm 0.71$ & $1.86 \pm 0.95$ \\
\hline Life quality & $1.73 \pm 1.02$ & $1.97 \pm 0.90$ \\
\hline Impact of work on life & $1.90 \pm 0.71$ & \\
\hline
\end{tabular}

PSQI - Pittsburgh Sleep Quality Index; ESS - Epworth Sleepiness Scale; * - significant at the $\mathrm{p}<0.05$ level;** - significant at the $\mathrm{p}<0.01$ level 
Table 2 Differences between groups at baseline of relative and absolute frequencies of threshold scores in PSQI and ESS

\begin{tabular}{lcc}
\hline & $\begin{array}{c}\mathbf{N}=\mathbf{3 0} \\
\text { relative } \\
\text { frequency } \\
\text { (absolute } \\
\text { frequency) }\end{array}$ & $\begin{array}{c}\mathbf{N}=\mathbf{1 5 4} \\
\text { relative } \\
\text { frequency } \\
\text { (absolute } \\
\text { frequency) }\end{array}$ \\
\hline PSQI & & \\
\hline Total score $>5 *$ & $33.3 \%(10)$ & $29.2 \%(45)$ \\
\hline Total score $>10^{* *}$ & $16.7 \%(5)$ & $18.2 \%(28)$ \\
\hline ESS & & \\
\hline Total score $>10^{* * *}$ & $26.7 \%(8)$ & $31.8 \%(49)$ \\
\hline
\end{tabular}

PSQI - Pittsburgh Sleep Quality Index; ESS - Epworth Sleepiness Scale; $*$-score indicating poor sleep quality; $* *$ - score indicating sleep disorders requiring clinical intervention; $* * *$ - score indicating sleep problems

Sleep coaching helped our participants to cope better with the demanding lifestyle of shift work. It encouraged them to be their own coaches. Their quality of sleep, quality of life, and daytime alertness improved, which is rather important, considering that many of the participants were train drivers. Accordingly, diurnal fatigue was significantly reduced after the seminar, which implies greater safety. Our results also showed an improvement in sleep latency which reduces unnecessary time in bed and might leave more time for social interactions. No significant reduction in consumption of sleep medication could be measured, probably due to the fact that the seminar was held by psychologists who were not licenced to prescribe medication and had a different focus in teaching.

In line with previous findings $(4,6,7)$, our shift workers showed somewhat higher BMI scores, but not significantly.
This report focuses on how sleep complaints in shift workers can be addressed by sleep coaching as a new approach to non-pharmacologic treatment of non-restorative sleep which includes psychotherapeutic aspects and enables patients to improve their quality of sleep and life by developing their own coping strategies. The crucial point here is that these strategies must become part of the daily bedtime routine.

Our finding may help to better design non-pharmacologic treatment of sleep-related complaints in the future, as it underlines promising strategies of coping with the demanding lifestyle of shift work.

\section{Limitations}

The heterogeneity of the sample with respect to shift work schedules and the duration of working in night shifts are limiting the interpretation of our findings, as it is difficult to compare field studies due to differences in test settings as well as demographic and individual differences of the participants $(38,39)$. To enhance external validity, future investigations should concentrate on comparable shift working schedules.

The selection of the sample may have been biased, since participation in the seminar and completion of the survey were voluntary. The motivation to act against the negative effects of shift work may have been higher in the participants who completed the follow-up. However, our comparison between the two groups showed significant differences only in burnout scores and sleep duration at baseline, which excludes bias in the completer group to a reasonable extent. The results of the remaining variables did not differ, and

Table 3 PSQI, ESS, burnout, sleep issues, life quality, and impact on life scores in shift workers at baseline and six months after the $\mathrm{SC}$ seminar

\begin{tabular}{lccc} 
& Baseline $(\mathbf{N}=\mathbf{3 0})$ & Follow-up $(\mathbf{N}=\mathbf{3 0})$ & \\
\cline { 2 - 4 } PSQI & mean \pm SD & mean \pm SD & Cohen's d*** \\
\hline Total score & & & 0.64 \\
\hline Subjective sleep quality & $7.07 \pm 2.79$ & $5.30 \pm 2.83^{* *}$ & 0.71 \\
\hline Sleep disorders & $1.43 \pm 0.50$ & $1.03 \pm 0.61^{* *}$ & \\
\hline Consumption of soporifics & $1.23 \pm 0.43$ & $1.10 \pm 0.31$ & 0.57 \\
\hline Diurnal fatigue & $0.17 \pm 0.65$ & $0.07 \pm 0.37$ & \\
\hline Sleep duration & $1.30 \pm 0.70$ & $0.90 \pm 0.71^{* *}$ & 0.52 \\
\hline Sleep latency & $0.47 \pm 0.73$ & $0.47 \pm 0.86$ & \\
\hline Sleep efficiency & $1.67 \pm 0.96$ & $1.20 \pm 0.81^{* *}$ & 0.50 \\
\hline ESS & $0.83 \pm 1.09$ & & \\
\hline Daytime Sleepiness & & & \\
\hline Additional variables & $8.73 \pm 3.75$ & $6.87 \pm 3.69^{* *}$ & \\
\hline Burnout & & $1.21 \pm 0.69$ & \\
\hline Sleep Issues & $1.03 \pm 0.60$ & $1.63 \pm 0.85$ & 0.40 \\
\hline Life quality & $1.90 \pm 0.71$ & $1.33 \pm 0.96^{*}$ & \\
\hline
\end{tabular}

PSQI - Pittsburgh Sleep Quality Index; ESS - Epworth Sleepiness Scale; * - significant at the $\mathrm{p}<0.05$ level; ** - significant at the $\mathrm{p}<0.01$ level; $* * *-\mathrm{d}=\mathrm{t}_{\mathrm{c}}[2(1-\mathrm{r}) / \mathrm{n}]^{1 / 2}$ [formula for Cohen's $\mathrm{d}$ by Dunlap et al. (36)] 


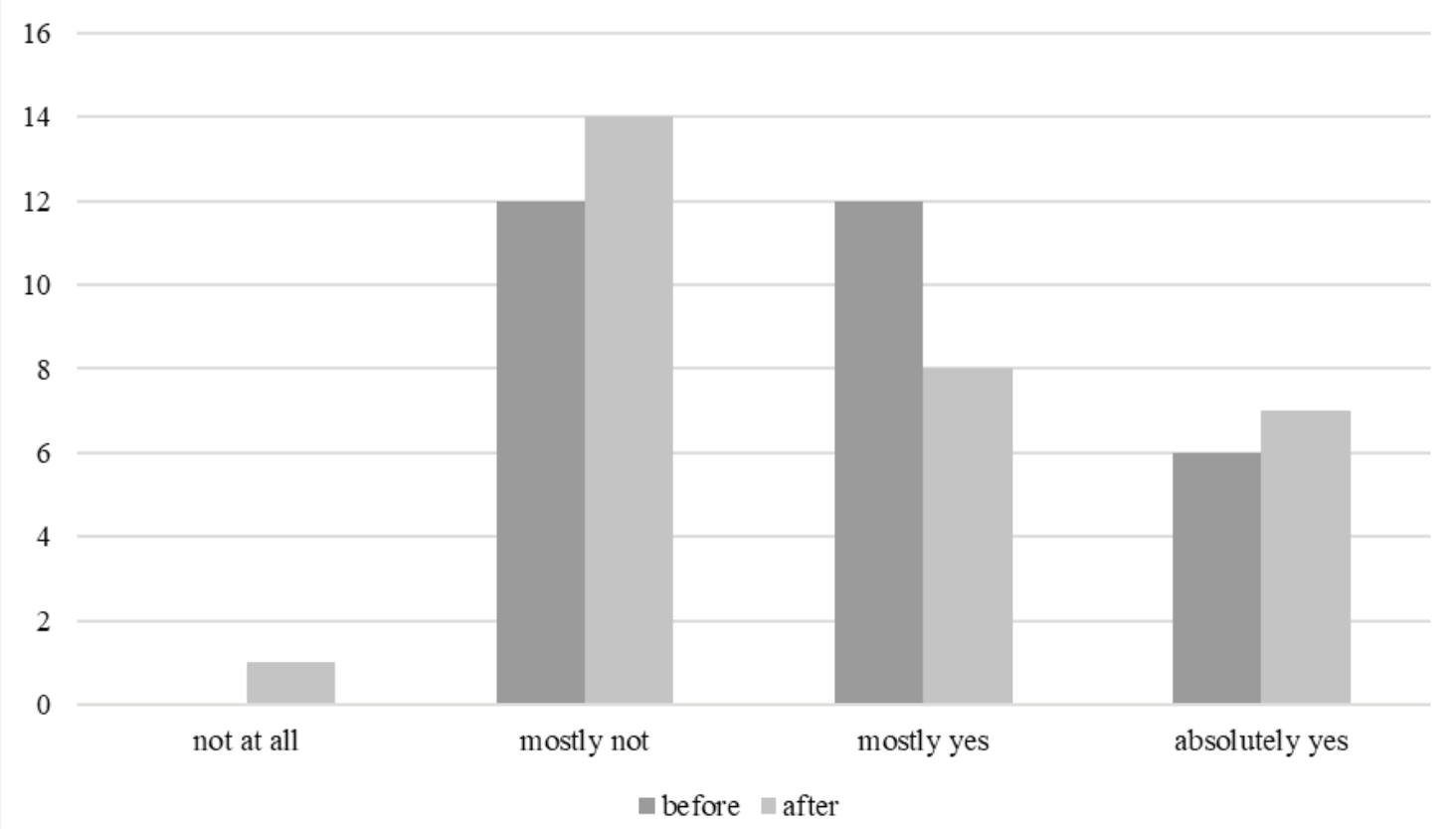

Figure 1 Responses to question "Do you have complaints due to shift work?" before and 6 months after the SC seminar

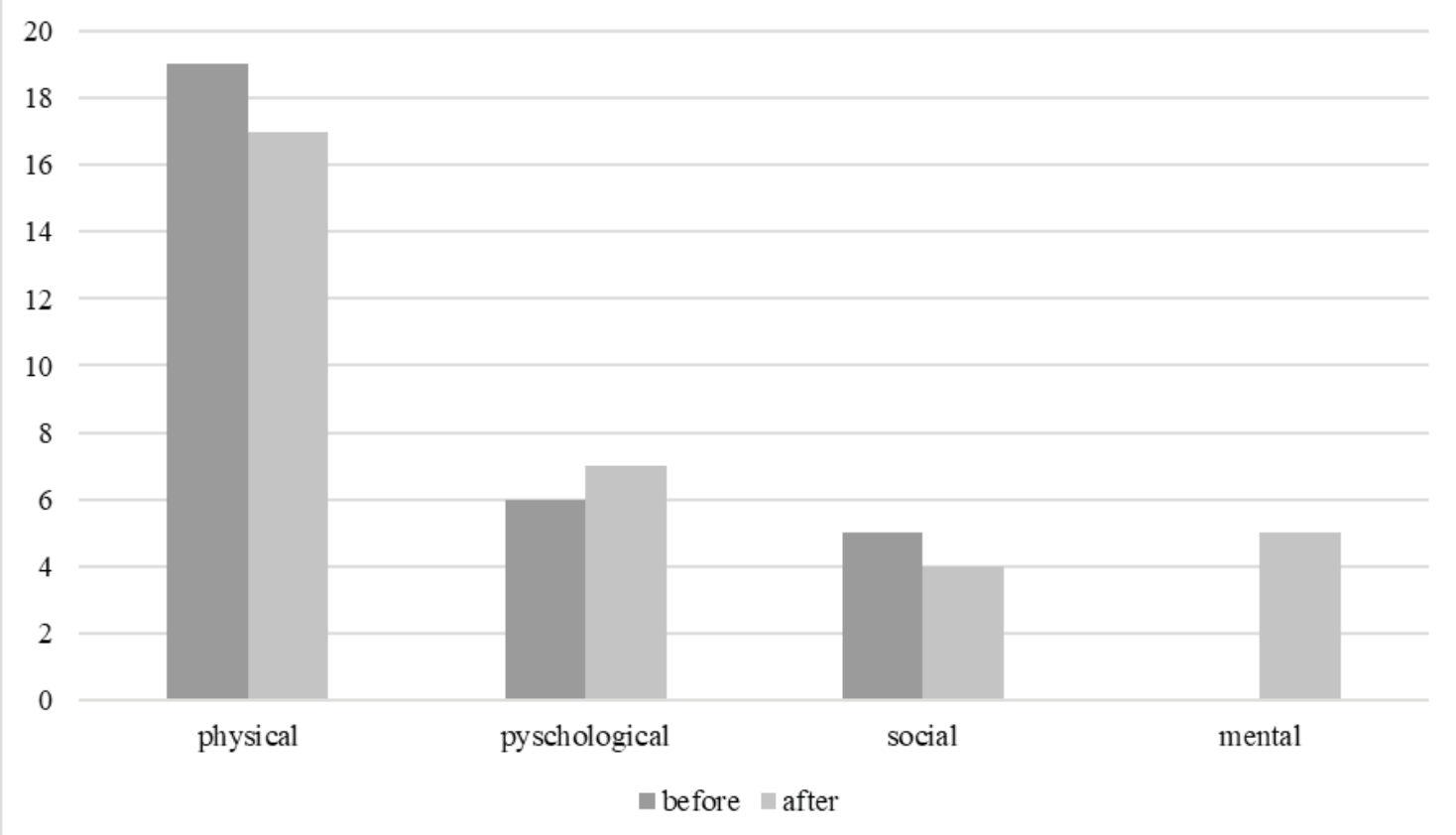

Figure 2 Distribution of complaints resulting from working schedules as reported by shift workers before and 6 months after the seminar (multiple responses possible) 
sleep duration does not seem to be as relevant for sleep quality because missed hours can be compensated on days off, as literature has shown (40).

Another limitation is that only self-reported data were used instead of information such as medical reports or activity monitoring by actigraphs. Burnout was assessed by only three questions. Therefore, its validation could include already established measurements like the Maslach Burnout Inventory. The same applies for perfectionism, which should be measured with more than two questions.

\section{Clinical implications and future research}

These limitations notwithstanding, the findings presented in this report provide an insight into the sleep issues of shift workers and possible treatment in a naturalistic setting. SC seems to be effective in improving sleep quality and reduce diurnal fatigue in shift workers. These findings can have particular relevance for employers who try to improve the well-being of their employees and sleeping behaviour. Our findings underscore the promising potential of holistic approaches such as SC on sleep issues of employees. Yet, future research analysing seminars of the kind should investigate their impact in a longer run for a larger sample size.

\section{Conflict of interest}

Authors Brigitte Holzinger and Gerhard Klösch have been involved in the design and application of the sleep coaching programme Holzinger \& Klösch ${ }^{\mathrm{TM}}$. Other authors declare no conflict of interest.

\section{REFERENCES}

1. Eurostat. Employees working shifts as a percentage of the total of employees, by sex and age (\%). [displayed 26 August 2019]. Available at https://appsso.eurostat.ec.europa.eu/nui/ submitViewTableAction.do

2. American Academy of Sleep Medicine. International Classification of Sleep Disorders, revised. Westchester (IL): American Academy of Sleep Medicine; 2001.

3. Drake CL, Roehrs T, Richardson G, Walsh JK, Roth T. Shift work sleep disorder: Prevalence and consequences beyond that of symptomatic day workers. Sleep 2004;27:1453-62. doi: 10.1093/sleep/27.8.1453

4. Knutsson A. Health disorders of shift workers. Occup Med 2003;53:103-8. doi: 10.1093/occmed/kqg048

5. Takahashi M. Assisting shift workers through sleep and circadian research. Sleep Biol Rhythms 2014;12:85-95. doi: 10.1111/sbr. 12065

6. Karlsson B, Knutsson A, Lindahl B. Is there an association between shift work and having a metabolic syndrome? Results from a population based study of 27485 people. Occup Environ Med 2001;58:747-52. doi: 10.1136/ oem.58.11.747

7. Niedhammer I, Lert F, Marne MJ. Prevalence of overweight and weight gain in relation to night work in a nurses cohort.
Int J Obes Relat Metab Disord 1996;20:625-33. PMID: 8817356

8. Vyas MV, Garg AX, Iansavichus AV, Costella JP, Donner A, Laugsand LES, Janszky I, Mrkobrada M, Parraga G, Hackam DG. Shift work and vascular events: systematic review and meta-analysis. BMJ 2012;345:e4800 doi: 10.1136/bmj.e4800

9. Jamal M. Burnout, stress and health of employees on nonstandard work schedules: a study of Canadian workers. Stress and Health 2014;20:113-9. doi: 10.1002/smi.1012

10. Stimpfel AW, Sloane DM, Aiken LH. The longer the shifts for hospital nurses, the higher the levels of burnout and patient dissatisfaction. Health Aff (Millwood) 2012;31:25019. doi: 10.1377/hlthaff.2011.1377

11. Akerstedt T, Nordin M, Alfredsson L, Westerholm P, Kecklund G. Sleep and sleepiness: impact of entering or leaving shiftwork - A prospective study. Chronobiol Int 2010;27:987-96. doi: 10.3109/07420528.2010.489423

12. Hossain JL, Shapiro CM. Considerations and possible consequences of shift work. J Psychosom Res 1999;47:2936. doi: 10.1016/S0022-3999(99)00073-2

13. Garbarino S, Beelke M, Costa G, Violani C, Lucidi F, Ferrillo F, Sannita WG. Brain function and effects of shift work: implications for clinical neuropharmacology. Neuropsychobiology 2002;45:50-6. doi: 10.1159/000048674

14. Cardofo R, Du F, Song N, Zhang K. Mind wandering, sleep quality, affect and chronotype: an exploratory study. PLoS One, 2014;9(3):e91285. doi: 10.1371/journal.pone.0091285

15. Juda M, Vetter C, Roenneberg T. Chronotype modulates sleep duration, sleep quality and social jet lag in shift workers. J Biol Rhythms 2013;28:141-51. doi: 10.1177/0748730412475042

16. Klösch G, Baldinger B, Bolitschek J. Chronotyp und Nachtdienst - vorläufige Ergebnisse einer Feldstudie [Chronotype and Night shift - preliminary results of a field study, in German]. Somnologie 2010;14:74. doi: 10.1007/ s11818-010-0489-2

17. Kerin A, Aquirre A. Improving health, safety, and profits in extended hours operations (shiftwork). Ind Health 2005;43:201-8. doi: 10.2486/indhealth.43.201

18. Morin CM, Hauri PJ, Espie CA, Spielman AJ, Buysse DJ, Bootzing RR. Nonpharmacological treatment of chronic insomnia: An American Academy of Sleep Medicine review. Sleep 1999;22:1134-56. doi: 10.1093/sleep/22.8.1134

19. Stepanski E, Wyatt JK. Use of sleep hygiene in the treatment of insomnia. Sleep Med Rev 2003;7:215-25. doi: 10.1053/ smrv.2001.0246

20. Morin CM, Bootzin RR, Buysse DJ, Edinger JD, Espie CA, Lichtenstein KL. Psychological and behavioral treatment of insomnia: Update of the recent evidence (1998-2004). Sleep 2006;29:1398-414. doi: 10.1093/sleep/29.11.1398

21. Lushington K, Lack L. Non-pharmacological treatments of insomnia. Isr J Psychiatry Relat Sci 2002;39:36-49. PMID: 12013709

22. Spielman AJ, Saskin P, Thorpy MJ. Treatment of chronic insomnia by restriction of time in bed. Sleep 1987;10:45-56. doi: 10.1093/sleep/10.1.45

23. Anbar RD, Slothower MP. Hypnosis for treatment of insomnia in school-age children: a retrospective chart review. BMC Pediatr 2006;6:23. doi: 10.1186/1471-2431-6-23

24. Cordi MJ, Schlarb AA, Rasch B. Deepening sleep by hypnotic suggestion. Sleep 2014;37:1143-52. doi: 10.5665/sleep.3778 
25. Ng BY, Lee TS. Hypnotherapy for sleep disorders. Ann Acad Med Singapore 2008;37:683-8. PMID: 18797562

26. Chesson AL Jr., McDowell Anderson W, Littner M, Davila D, Hartse K, Johnsin S, Wise M, Rafecas J. Practice parameters for the nonpharamcologic treatment of chronic insomnia. Sleep 1999:22:1128-33. doi: 10.1093/ sleep/22.8.1128

27. Schoicket SL, Bertelson AD, Lacks P. Is sleep hygiene a sufficient treatment for sleep-maintenance insomnia? Behav Ther 1988;19:183-90. doi: 10.1016/S0005-7894(88)80041-8

28. Röttger S, Maier J, Krex-Brinkemann L, Kowalski J, DankerHopfe H, Sauter C, Stein M. The benefits of sleep coaching in workplace health promotion. J Public Health 2017;25:68591. doi: 10.1007/s10389-017-0826-Z

29. Holzinger B, Klösch G. Schlafchoaching: Wer wach sein will, muss schlafen [Sleep coaching: who wants to be awake needs to sleep, in German]. Wien: Goldegg Verlag GmbH; 2013.

30. Strümpfel U. Therapie der Gefühle. Forschungsbefunde zur Gestalttherapie [Therapy of feelings. Research findings concerning Gestalt therapy, in German]. Bergisch Gladbach: EHP; 2006.

31. Holzinger B, Klösch G, Saletu B. Studies with lucid dreaming as add-on therapy to Gestalt therapy. Acta Neurol Scand 2015;131:355-63. doi: 10.1111/ane.12362

32. Buysse DJ, Reynolds CF, Monk TH, Berman SR, Kupfer DJ The Pittsburgh Sleep Quality Index: A new instrument for psychiatric practice and research. Psychiatry Res 1989;28:193-213. doi: 10.1016/0165-1781(89)90047-4
33. Backhaus J, Junghanns K, Broocks A, Reimann D, Hohagen F. Test-retest reliability of the Pittsburgh Sleep Quality Index in primary insomnia. J Psychosom Res 2002;53:737-40. doi: 10.1016/S0022-3999(02)00330-6

34. Johns MW. A new method for measuring daytime sleepiness: the Epworth sleepiness scale. Sleep 1991;14:540-5. doi: 10.1093/sleep/14.6.540

35. Johns MW. Reliability and factor analysis of the Epworth Sleepiness Scale. Sleep 1992;15:376-81. doi: 10.1093/ sleep $/ 15.4 .376$

36. Randler C, Schaal S. Morningness-eveningness, habitual sleep-wake variables and cortisol level. Biol Psychol 2010;85:14-8. doi: 10.1016/j.biopsycho.2010.04.006

37. Dunlap WP, Cortina JM, Vaslow JB, Burke MJ. Meta-analysis of experiments with matched groups or repeated measures designs. Psychol Methods 1996;1:170. doi: 1082-989X/96/\$3.W

38. De Almondes KM, Araújo JF. Sleep quality and daily lifestyle regularity in workers with different working hours. Biol Rhythm Res 2011;42:231-45. doi: 10.1080/09291016. 2010.509480

39. Holdevici I. Relaxation and hypnosis in reducing anxiousdepressive symptoms and insomnia among adults. Procedia - Soc Behav Sci 2014;127:586-90. doi: 10.1016/j. sbspro.2014.03.315

40. Frese M, Harwich C. Shift work and the length and quality of sleep. J Occup Med 1984;26:561-6. PMID: 6481495

\section{Sleep coaching: nefarmakološko liječenje neokrepljujućeg spavanja u smjenskih radnika na austrijskoj željeznici}

Sleep coaching (vođenje spavanja) je novi holistički pristup nefarmakološkom liječenju neokrepljujućega sna koji su osmislili Holzinger \& Klösch ${ }^{\mathrm{TM}}$. Obuhvaća psihoterapijske oblike koji korisnicima omogućuju da poprave kvalitetu spavanja tako što će razviti vlastite svakodnevne strategije kako se nositi s tim problemom. Program također obuhvaća rad na snu i tehnike opuštanja. Cilj je ovoga istraživanja bio utvrditi djelotvornost dvodnevnoga seminara iz spavanja na poboljšanje kvalitete spavanja, dnevnu pospanost te na kvalitetu rada i života smjenskih radnika jedne austrijske željezničke tvrtke (Österreichische Bundesbahnen, ÖBB). Istraživanje je obuhvatilo 30 radnika (28 muškaraca i dvije žene, srednja dob 24 $\pm 45,90$ godina, u dobnom rasponu od 24 do 56 godina) koji su odgovorili na upitnik prije seminara te šest mjeseci nakon njega da bi se utvrdile početne vrijednosti i promjene. Upitnik je sadržavao pitanja iz Pittsburgh indeksa kvalitete spavanja (izv. Pittsburgh Sleep Quality Index, krat. PSQI) i iz Epworthove ljestvice pospanosti (izv. Epworth Sleepiness Scale, krat. ESS), zatim kronotip ispitanika, čimbenike osobnosti i rizične čimbenike za izgaranje na poslu (engl. burn$o u t)$. Početne su vrijednosti u ovoj skupini uspoređene s početnim vrijednostima u skupini koja nije ispunila upitnik nakon seminara $(\mathrm{N}=154)$ kako bi se utvrdilo razlikuju li se te dvije skupine dovoljno da se može pretpostaviti otklon (engl. bias) u skupini koja je ispunila upitnik nakon seminara. Dvije su se skupine razlikovale samo razinom izgaranja na poslu i trajanjem spavanja, ali ne i distribucijom vrijednosti iz PSQI i ESS upitnika. Dvodnevni je seminar iz vođenja spavanja u skupini koja je ispunila upitnik nakon seminara doveo do značajnoga poboljšanja u ukupnim bodovima iz PSQI upitnika te do značajnoga smanjenja dnevnoga umora, odgode spavanja i dnevne pospanosti. S obzirom na mali uzorak, potrebno je provesti veće longitudinalno istraživanje s većim uzorkom kako bi se utvrdili dugotrajni učinci vođenja spavanja. 